\title{
Out-Patient Attitude towards Hospitals during COVID-19 in India
}

\author{
SIJI OLIVER ${ }^{1}$, C. L. JEBA MELVIN ${ }^{2}$ \\ ${ }^{1}$ Ph.D. Research Scholar (Regd.19223111062056), Research Centre of Management Studies, Nesamony \\ Memorial Christian College, Marthandam, affiliated to MANONMANIAM SUNDARANAR UNIVERSITY, TAMIL \\ NADU, INDIA. Email: seej23@gmail.com \\ ${ }^{2}$ Associate Professor \& Head of Research Centre of Management Studies, Nesamony Memorial Christian \\ College, Marthandam affiliated to MANONMANIAM SUNDARANAR UNIVERSITY, TAMIL NADU, INDIA \\ Email: jebamelwyn@gmail.com
}

\begin{abstract}
COVID-19, one of the worst pandemics in recent years, have changed the face of our world. Every sector has been experiencing a tug in unexpected directions than anticipated. Often it is said that the healthcare sector is facing a boom in this COVID-19 episode, nevertheless there has been a decline of out-patient segment in hospitals. An out-patient is one who visits a hospital for treatment without staying overnight. Through this time of uncertainty where a new normal is being burgeoned, the people's attitude towards healthcare has shifted a great deal. Predominantly out-patients are hesitant to continue with their regular physician visits by delaying or avoiding unneeded visits. People with underlying diseases, both which are at low risk or at high risk, find themselves at higher caution due to the COVID-19. This study focuses to understand the attitude of outpatients and of out-patients with risk during this COVID-19 pandemic towards hospitals in India. Online or Tele medical consultation has picked up momentum among out-patients during the COVID-19 Unlock phase which shines a possibility as a new normal in the healthcare industry.
\end{abstract}

Keywords: Patient; Outpatient attitude; COVID-19; Hospital; Pandemic; Coronavirus; Online medical consultation; Unlock.

JEL Classification: C1, L2

Received: June 03, 2021

Accepted: September 13, 2021 


\title{
Actitud de los Pacientes Externos hacia los Hospitales durante COVID-19 en la India
}

\author{
SIJI OLIVER ${ }^{1}$, C. L. JEBA MELVIN ${ }^{2}$ \\ ${ }^{1}$ Ph.D. Research Scholar (Regd.19223111062056), Research Centre of Management Studies, Nesamony \\ Memorial Christian College, Marthandam, affiliated to MANONMANIAM SUNDARANAR UNIVERSITY, TAMIL \\ NADU, INDIA. Email: seej23@gmail.com \\ ${ }^{2}$ Associate Professor \& Head of Research Centre of Management Studies, Nesamony Memorial Christian \\ College, Marthandam affiliated to MANONMANIAM SUNDARANAR UNIVERSITY, TAMIL NADU, INDIA \\ Email: jebamelwyn@gmail.com
}

\begin{abstract}
RESUMEN
COVID-19, una de las peores pandemias de los últimos años, ha cambiado la faz de nuestro mundo. Todos los sectores han experimentado un tirón en direcciones inesperadas de las previstas. A menudo se dice que el sector sanitario se enfrenta a un boom en este episodio de COVID-19, sin embargo se ha producido un descenso del segmento de pacientes externos en los hospitales. Un paciente externo es aquel que acude a un hospital para recibir tratamiento sin pasar la noche. En esta época de incertidumbre en la que se está gestando una nueva normalidad, la actitud de la gente hacia la asistencia sanitaria ha cambiado mucho. Predominan los pacientes externos que dudan en continuar con sus visitas regulares al médico, retrasando o evitando las visitas innecesarias. Las personas con enfermedades subyacentes, tanto de bajo como de alto riesgo, se encuentran en una situación de mayor precaución debido al COVID-19. Este estudio se centra en comprender la actitud de los pacientes externos y de los pacientes externos con riesgo durante esta pandemia de COVID-19 hacia los hospitales de la India. La consulta médica en línea o a distancia ha cobrado impulso entre los pacientes externos durante la fase de desbloqueo de la COVID-19, lo que hace pensar en una nueva normalidad en el sector sanitario.
\end{abstract}

Palabras clave: Paciente; Actitud ambulatoria; COVID-19; Hospital; Pandemia; Coronavirus; Consulta médica en línea; Desbloqueo.

Clasificación JEL: C1, L2

Recibido: 03 de Junio de 2021

Aceptado: 13 de Septiembre de 2021 


\section{Introduction}

Coronavirus disease; the extremely feared pandemic of the century, has taken over and flipped the normal functioning in the world. Summed up as the COVID-19 by the World Health Organization, it is a disease that spreads rapidly through contact which comes along with flu-like symptoms and in severe cases leads to respiratory issues. The fatality of the disease is unanticipated in COVID-19 and there is no proved protocol for the cure. This has led to drastic measures to contain the disease and has also created sceptical and pessimistic feelings among the people.

A patient is someone who visits a hospital or healthcare facility to regain respite from their physical or mental indisposition. An out-patient is a patient who visits the hospital and does not stay over-night for further medical treatment. Hospitals and many Healthcare facilities have become relief zones for COVID-19 treatment and potentially pose a risk to out-patients who would require to visit for other illnesses and treatments.

Over the COVID-19 lockdown period, out-patients have reduced their regular visits to the hospital as they prefer to avoid exposure and the possibility of contracting the Coronavirus disease. Outpatients with risk are unable to find safe arrangements to continue their routine consultations. The nation has moved forward to unlock the lockdown in different phases. During the unlock phases, with the freedom to step out in most zones, the out-patient attitudes have changed and are unlikely to get back to normal in the impending future.

Healthcare providers have electively converted to telemedicine or e-medical consultation for their first time consulting to derive medical history and even for regular out-patients. (Zhou et al., 2020 p.575) points out that; "Online outpatient service was created mainly to provide prescriptions to existing patients and to offer consultation to new patients"

\section{Objectives of the Study}

1. To assess out-patient attitude in Rural, Urban and Semi-urban locations towards private healthcare facilities during COVID-19

2. To ascertain out-patients with underlying health issues and with risk during COVID-19

3. To find out the attitude of out-patients towards online medical consultation

\section{Review of Literature}

(World Health Organization [WHO], 2020) has declared the COVID-19 outbreak a pandemic, where the disease may manifest either as an asymptomatic infection or a mild to severe pneumonia. (Fauci et al., 2020) affirms that the latest threat to the global health declared as the pandemic is the ongoing outbreak of respiratory disease named Coronavirus Disease 2019 (COVID-19). (Hollander \& Carr, 2020a) have highlighted that disasters and pandemics pose unique challenge to healthcare delivery.

(Merriam-Webster, n.d) defines a patient as an individual awaiting or under medical care and treatment. An outpatient is one who is not hospitalized overnight but who visits a hospital, clinic, or associated facility for diagnosis or treatment.

(Roy et al., 2020) has foregrounded that pandemics can lead to higher stress levels; Anxiety or Fear is a common response to any stressful situation. There are increased apprehensions and worries among the public regarding contracting the COVID-19 virus.

Due to the recent nature of risk in the pandemic, alternative measures have been attempted to ensure outpatients are given care and support. (Mehrotra, Ray, Brockmeyer, Barnett, \& Bender, 2020) expresses that "For patients who have non-Covid-19 issues, tele-health can allow them to receive care without the risk of exposure - a critical concern for older adults and those with chronic conditions". (Hollander \& Carr, 2020b, p.1679) states "Direct-to-consumer (or on-demand) telemedicine, a $21^{\text {st }}$ century approach to forward triage that allows patients to be efficiently 
screened, is both patient-cantered and conducive to self-quarantine, and it protects patients, clinicians, and the community from exposure. It can allow physicians and patients to communicate $24 / 7$, using smartphones or webcam-enabled computers."

\section{Methodology of the Study}

Data was collected from primary as well as secondary sources. A descriptive design for research was applied. The primary data was collected through an organized questionnaire where, the first part comprises of the demographic profile, second part directed to ascertain out-patients with underlying health issues and with risk due to COVID-19 with the third part as a five point Likert scale with statements set to understand the attitude of out-patients during COVID-19. The sample size was 89 ,where the target respondents were out-patients and out-patients with risk, during the transition of COVID-19 lockdown period to Unlock period in India.

\section{Data Analysis and Interpretation}

Figure 1 Gender

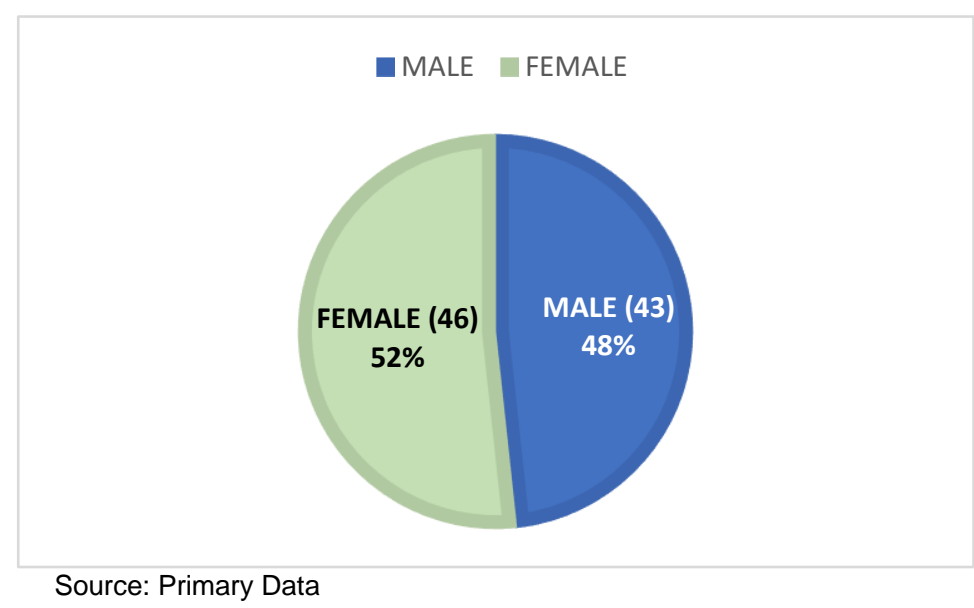

It is inferred from Figure 1 that from 89 respondents, 48\% (43 responses) are Males and $52 \%$ (46 responses) are Females.

Figure 2 Out-patients with underlying health conditions

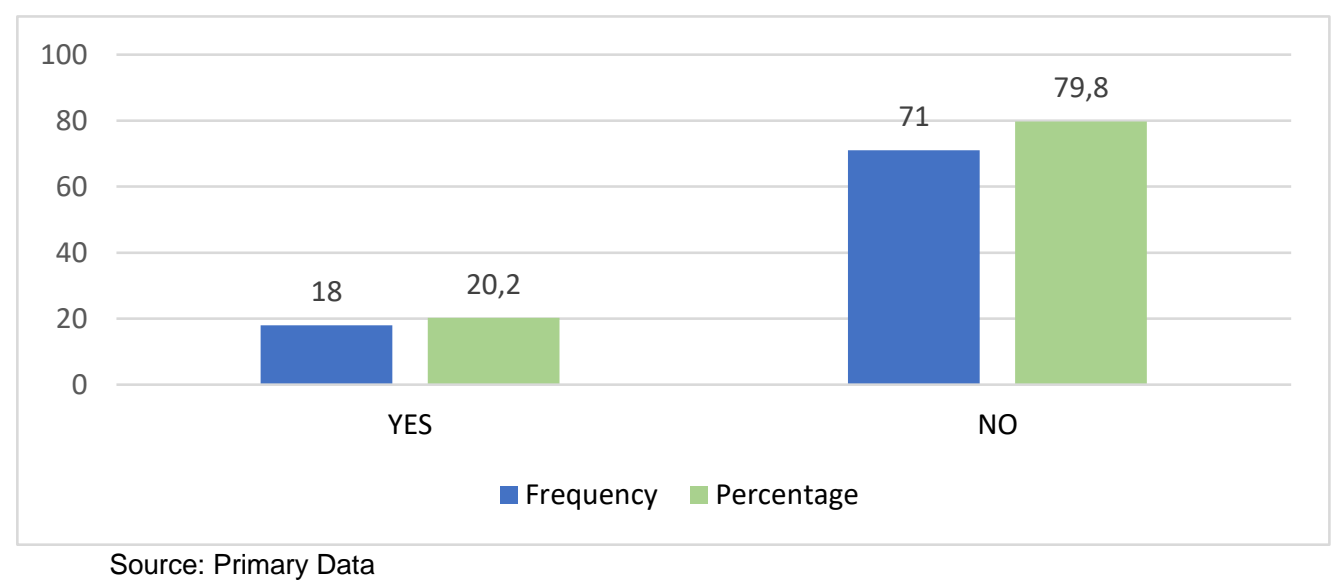

It is inferred from Figure 2 that from 89 respondents, 20.2\% (18 responses) have underlying health conditions and $79.8 \%$ (71 responses) do not have any underlying health conditions. 
Figure 3 Out-patients at high risk due to COVID-19

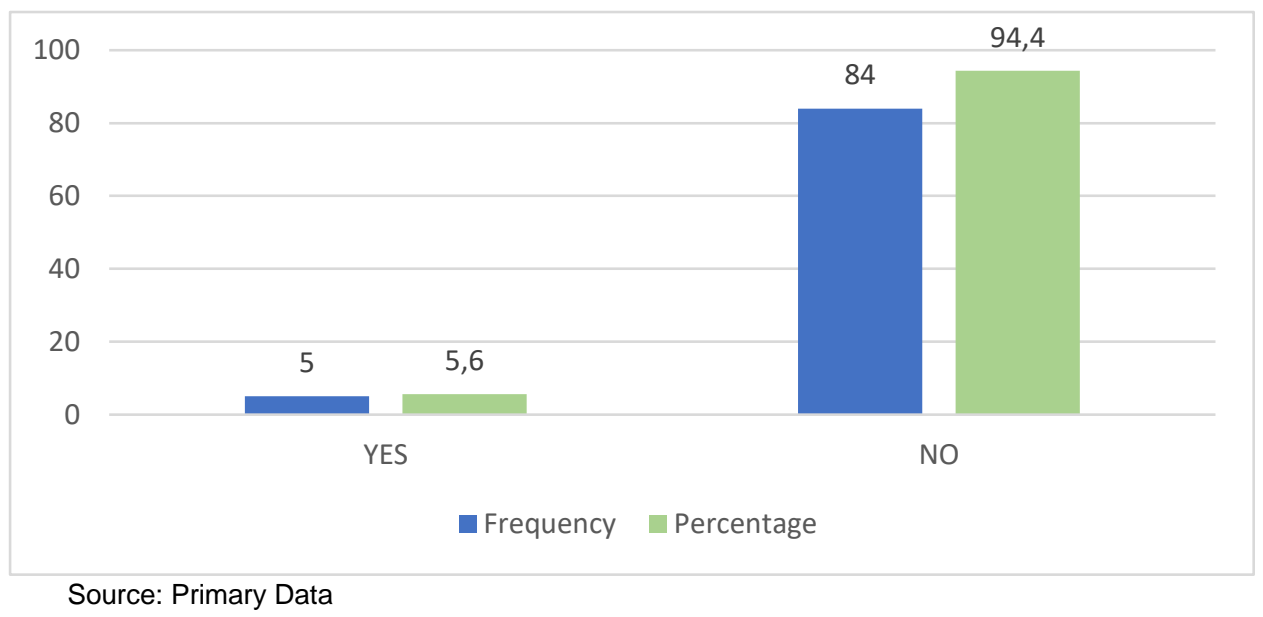

It is inferred from figure 3 that from 89 respondents, 5.6\% (5 responses) are at higher risk due to COVID-19 pandemic and $94.4 \%$ (84 responses) are free from health risk.

Table 1 Attitude Of Out-patients towards Healthcare During COVID-19

\begin{tabular}{|c|c|c|c|c|c|}
\hline \multirow{2}{*}{$\begin{array}{l}\text { Attitude Towards } \\
\text { Healthcare During } \\
\text { Covid-19 }\end{array}$} & \multicolumn{3}{|c|}{ Location } & \multirow{2}{*}{ F- Value } & \multirow{2}{*}{ P-Value } \\
\hline & Rural & Urban & $\begin{array}{l}\text { Semi- } \\
\text { Urban }\end{array}$ & & \\
\hline \multirow{2}{*}{$\begin{array}{l}\text { Shifting to a safer } \\
\text { method of } \\
\text { medication } \\
\text { purchase or } \\
\text { healthcare facility }\end{array}$} & 3.580 & 3.120 & 2.420 & \multirow[b]{2}{*}{2.709} & \multirow[b]{2}{*}{0.072} \\
\hline & (1.505) & $(1.428)$ & (1.427) & & \\
\hline \multirow{2}{*}{$\begin{array}{c}\text { Feeling of High risk } \\
\text { in contracting } \\
\text { COVID-19 }\end{array}$} & 3.500 & 2.600 & 3.470 & \multirow{2}{*}{4.626} & \multirow{2}{*}{$0.012 *$} \\
\hline & (1.314) & $(1.270)$ & (1.389) & & \\
\hline \multirow{2}{*}{$\begin{array}{c}\text { Confidence to visit } \\
\text { my usual } \\
\text { healthcare facility }\end{array}$} & 2.500 & 2.410 & 2.000 & \multirow{2}{*}{0.824} & \multirow{2}{*}{0.442} \\
\hline & $(1.446)$ & $(1.312)$ & $(1.202)$ & & \\
\hline \multirow{2}{*}{$\begin{array}{l}\text { The healthcare } \\
\text { visited has taken } \\
\text { adequate COVID- } \\
19 \text { prevention } \\
\text { measures }\end{array}$} & 3.080 & 3.020 & 2.580 & \multirow[b]{2}{*}{0.994} & \multirow[b]{2}{*}{0.374} \\
\hline & $(1.443)$ & $(1.235)$ & (1.121) & & \\
\hline
\end{tabular}

The values in brackets indicate the Standard Deviation

$\mathrm{H}_{0}$ : There is no significant difference between Location with Attitude of out-patients towards Healthcare During COVID-19

It is inferred from Table 1 , that P-value $0.012 *$ is less than 0.05 where $\mathrm{H}_{0}$ is rejected at $5 \%$ level significance stating that out-patients in all locations; Rural, Urban and Semi-Urban feel at higher risk in contracting the COVID-19. 
Table 2 Attitude of Out-patients towards visiting Healthcare during COVID-19

\begin{tabular}{|c|c|c|c|c|c|}
\hline \multirow{2}{*}{$\begin{array}{l}\text { Attitude Towards } \\
\text { Visiting } \\
\text { Healthcare Facility } \\
\text { During Covid-19 }\end{array}$} & \multicolumn{3}{|c|}{ Location } & \multirow[b]{2}{*}{ F- Value } & \multirow[b]{2}{*}{ P-Value } \\
\hline & Rural & Urban & $\begin{array}{l}\text { Semi- } \\
\text { Urban }\end{array}$ & & \\
\hline \multirow{2}{*}{$\begin{array}{l}\text { Develops one or } \\
\text { more symptoms of } \\
\text { COVID-19 }\end{array}$} & 3.170 & 3.140 & 2.790 & \multirow{2}{*}{0.459} & \multirow{2}{*}{0.634} \\
\hline & (1.403) & (1.456) & (1.357) & & \\
\hline \multirow{2}{*}{$\begin{array}{l}\text { Family member } \\
\text { develops one or } \\
\text { more symptoms of } \\
\text { COVID-19 }\end{array}$} & 3.250 & 3.210 & 2.840 & \multirow[b]{2}{*}{0.547} & \multirow[b]{2}{*}{0.581} \\
\hline & (1.603) & $(1.386)$ & (1.214) & & \\
\hline \multirow{2}{*}{$\begin{array}{l}\text { Self-diagnosis with } \\
\text { one or more of } \\
\text { COVID-19 } \\
\text { symptoms }\end{array}$} & 2.920 & 2.840 & 2.740 & \multirow{2}{*}{0.073} & \multirow{2}{*}{0.930} \\
\hline & (1.443) & (1.374) & $(1.240)$ & & \\
\hline \multirow{2}{*}{$\begin{array}{l}\text { Develops any } \\
\text { other physical } \\
\text { discomfort } \\
\end{array}$} & 3.250 & 3.090 & 3.050 & \multirow{2}{*}{0.089} & \multirow{2}{*}{0.915} \\
\hline & (1.765) & (1.274) & $(1.268)$ & & \\
\hline \multirow{2}{*}{$\begin{array}{c}\text { Family member } \\
\text { develops any other } \\
\text { physical } \\
\text { discomfort }\end{array}$} & 3.580 & 3.220 & 3.210 & \multirow{2}{*}{0.414} & \multirow[b]{2}{*}{0.663} \\
\hline & (1.564) & (1.229) & $(1.273)$ & & \\
\hline \multirow{2}{*}{$\begin{array}{l}\text { Self-diagnosis with } \\
\text { any other physical } \\
\text { discomfort }\end{array}$} & 2.080 & 2.740 & 2.420 & \multirow{2}{*}{1.735} & \multirow{2}{*}{0.183} \\
\hline & (1.240) & (1.236) & (1.017) & & \\
\hline \multirow{2}{*}{$\begin{array}{c}\text { Suggesting } \\
\text { another person } \\
\text { with COVID-19 }\end{array}$} & 3.420 & 3.720 & 3.320 & \multirow{2}{*}{0.918} & \multirow{2}{*}{0.403} \\
\hline & (1.676) & (1.152) & (1.204) & & \\
\hline
\end{tabular}

Source: Primary Data

The values in brackets indicate the Standard Deviation

$\mathrm{H}_{0}$ : There is no significant difference between Location with Attitude of Out-patients towards visiting Healthcare during COVID-19.

It is inferred from Table 2, that P-values of out-patients attitude towards visiting healthcare facility during Covid-19 is greater than 0.05 . Hence $\mathrm{H}_{0}$ is accepted at $5 \%$ level significance stating there is no significant difference between the location of out-patient towards their attitude of visiting healthcare during COVID-19. 
Siji Oliver, C. L. Jeba Melvin

Table 3 Attitude of Out-patients towards Other Healthcare facilities during COVID-19

\begin{tabular}{|c|c|c|c|c|c|}
\hline \multirow{2}{*}{$\begin{array}{l}\text { Attitude Towards Other } \\
\text { Healthcare Facilities } \\
\text { During Covid-19 }\end{array}$} & \multicolumn{3}{|c|}{ Location } & \multirow{2}{*}{ F- Value } & \multirow{2}{*}{ P-Value } \\
\hline & Rural & Urban & $\begin{array}{l}\text { Semi- } \\
\text { Urban }\end{array}$ & & \\
\hline \multirow{2}{*}{$\begin{array}{l}\text { Private Hospitals should } \\
\text { avoid COVID-19 patients }\end{array}$} & 2.420 & 2.170 & 2.420 & \multirow{2}{*}{0.301} & \multirow{2}{*}{0.741} \\
\hline & $(1.782)$ & $(1.365)$ & $(1.387)$ & & \\
\hline \multirow{2}{*}{$\begin{array}{l}\text { Confidence to visit non- } \\
\text { clinical areas }\end{array}$} & 2.420 & 2.160 & 1.840 & \multirow{2}{*}{1.126} & \multirow{2}{*}{0.329} \\
\hline & (1.165) & $(1.073)$ & $(1.015)$ & & \\
\hline \multirow{2}{*}{$\begin{array}{l}\text { Healthcare facility are the } \\
\text { environment for COVID- } \\
19 \text { spread }\end{array}$} & 3.330 & 3.090 & 3.740 & \multirow{2}{*}{1.772} & \multirow{2}{*}{0.176} \\
\hline & $(1.826)$ & $(1.274)$ & (1.046) & & \\
\hline \multirow{2}{*}{$\begin{array}{c}\text { Separate and safe areas } \\
\text { with special screening is } \\
\text { required }\end{array}$} & 4.170 & 4.030 & 4.000 & \multirow{2}{*}{0.089} & \multirow{2}{*}{0.915} \\
\hline & $(1.403)$ & (1.059) & (1.106) & & \\
\hline \multirow{2}{*}{$\begin{array}{c}\text { World Health } \\
\text { Organization guidelines } \\
\text { and Protocols are } \\
\text { followed }\end{array}$} & 2.750 & 3.260 & 3.260 & \multirow{2}{*}{0.872} & \multirow{2}{*}{0.422} \\
\hline & $(1.357)$ & (1.163) & (1.408) & & \\
\hline
\end{tabular}

Source: Primary Data

The values in brackets indicate the Standard Deviation

$\mathrm{H}_{0}$ : There is no significant difference between Location with Attitude of Out-patients towards other Healthcare facilities during COVID-19.

It is inferred from Table 3, that P-values of outpatients attitude towards other healthcare facility during Covid-19 is greater than 0.05 . Hence $\mathrm{H}_{0}$ is accepted at $5 \%$ level significance stating there is no significant difference between the location of out-patient towards their attitude of other healthcare facilities during COVID-19.

Table 4 Attitude of Out-patients towards Online Medical Consultation during COVID-19

\begin{tabular}{|c|c|c|c|c|c|}
\hline \multirow{2}{*}{$\begin{array}{c}\text { Attitude Towards } \\
\text { Online Medical } \\
\text { Consultation }\end{array}$} & \multicolumn{3}{|c|}{ Location } & \multirow[b]{2}{*}{ F- Value } & \multirow[b]{2}{*}{ P-Value } \\
\hline & Rural & Urban & $\begin{array}{l}\text { Semi- } \\
\text { Urban }\end{array}$ & & \\
\hline \multirow{2}{*}{$\begin{array}{l}\text { Looking forward to use } \\
\text { online medical } \\
\text { consultation }\end{array}$} & 3.500 & 3.020 & 3.160 & \multirow{2}{*}{0.558} & \multirow{2}{*}{0.575} \\
\hline & (1.624) & (1.481) & (1.259) & & \\
\hline \multirow{2}{*}{$\begin{array}{l}\text { Online medical } \\
\text { consultation for the } \\
\text { first time }\end{array}$} & 3.080 & 3.090 & 2.630 & \multirow{2}{*}{0.799} & \multirow{2}{*}{0.453} \\
\hline & (1.165) & $(1.430)$ & (1.383) & & \\
\hline
\end{tabular}

Source: Primary Data

The values in brackets indicate the Standard Deviation

$\mathrm{H}_{0}$ : There is no significant difference between Location with Attitude of Out-patients towards Online Medical Consultation during COVID-19

It is inferred from Table 4 that P-values of outpatients attitude towards online medical consultation during Covid-19 is greater than 0.05 . Hence $H_{0}$ is accepted at $5 \%$ level significance stating there is no significant difference between the location of out-patient towards online medical consultation during COVID-19. 


\section{Findings and Conclusion}

From this study it is found that the majority, $52 \%$ of respondents were Females. A minority of $20.2 \%$ respondents were found to have underlying health issues and $5.6 \%$ of respondents with higher risk due to COVID-19.

The COVID-19 having a swift rate of spread, mortality and with no near complete future cure or vaccine available; people have developed the fear of contracting the Coronavirus Disease 2019. An awareness about COVID-19 along with trepidation, it is observed that if the person or their family member experience one or more of the COVID-19 symptoms (cough, sore throat and fever) are willing to visit a healthcare facility to receive proper treatment and care. The respondents have also affirmed that they would suggest another person with one or more COVID-19 symptoms (cough, sore throat and fever) to visit a healthcare facility.

It is evident to notice that respondents feel that healthcare facilities have prepped and equipped themselves to curb the spread of COVID-19 taking maximum precautions such as, separate and safe areas with special screening and following World Health Organization guidelines. The respondents also feel safe and comfortable to visit their usual healthcare facility and has not considered to shift to consult any other healthcare facility during the COVID-19 lockdown period in India.

The people have understood the grim situation around and are willing to try online or telemedical consultation. This has a wide array of methods that can be used according to convenience. It can also be used for first time medical consultation where the healthcare provider can assess if the patient needs to visit a healthcare premise or avoid unnecessary exposure and scrimp time. Altogether this has caused a decline in out-patient segment in a hospital where a pre-assessment diminishes the patient from visiting a hospital.

\section{References}

1. Fauci, A. S., Lane, H. C., \& Redfield, R. R. (2020, March 26). Covid-19 - Navigating the uncharted. New England Journal of Medicine. Massachusetts Medical Society. doi: 10.1056/NEJMe2002387

2. Gao, Y., Sun, F., Jiang, W., et al. (2020). Beliefs towards the COVID-19 pandemic among patients with emotional disorders in China General Psychiatry. 33(3), e100231. doi: 10.1136/gpsych-2020100231

3. Hollander, J. E., \& Carr, B. G. (2020). Virtually perfect? Telemedicine for COVID-19. New England Journal of Medicine, 382(18), 1679-1681. doi:10.1056/NEJMp2003539

4. India's hospitals reel from outpatient slump.(2020, April 20th). Healthcare Asia. Retrieved from https://healthcareasiamagazine.com/healthcare/news/indias-hospitals-reel-outpatient-slump

5. Kurian, C.M. (2020, April 4th). How Kerala's People-Centric Health System Built Over 24 Years Is Paying Off Now. Huffpost-India Edition. Retrieved from

https://www.huffingtonpost.in/entry/kerala-people-centric-health-system-

coronavirus_in_5e875d55c5b6a9491835cb9e

6. Mehrotra, A., Chernew, M., Linetsky, D., Hatch, H., \& Cutler, D. (2020). The impact of the COVID19 pandemic on outpatient visits: a rebound emerges. The Commonwealth Fund. doi: $10.26099 / \mathrm{ds} 9 \mathrm{e}-\mathrm{jm} 36$

7. Mehrotra, A., Ray, K., Brockmeyer, D. M., Barnett, M. L., \& Bender, J. A. (2020). Rapidly converting to "virtual practices": outpatient care in the era of Covid-19. New England Journal of Medicine catalyst innovations in care delivery. 1(2). doi: 10.1056/CAT.20.0091

8. Nabae, K. (2003). The health care system in Kerala: its past accomplishments and new challenges. Journal of the National Institute of Public Health, 52(2), 140-5.

9. Nagarajan, R., Dhar, S. How Covid war is hurting India's Non-Covid patient. (2020, April 3rd). Times of India. Retrieved from https://timesofindia.indiatimes.com/india/how-covid-war-is-hurtingindias-non-covid-patients/articleshow/74949121.cms 
10.Rao, S. S., Loeb, A. E., Amin, R. M., Golladay, G. J., Levin, A. S., \& Thakkar, S. C. (2020). Establishing telemedicine in an academic total joint arthroplasty practice: needs and opportunities highlighted by the COVID-19 pandemic. Arthroplasty Today, 6(3), 617-623. doi: 10.1016/j.artd.2020.04.014

11.Reuken, P. A., Rauchfuss, F., Albers, S., Settmacher, U., Trautwein, C., Bruns, T., \& Stallmach, A. (2020). Between Fear and Courage: Attitudes, Beliefs, and Behavior of Liver Transplantation Recipients and Waiting List Candidates during the COVID-19 Pandemic. American Journal of Transplantation, 1-9. doi: 10.1111/ajt.16118

12.Roy, D., Tripathy, S., Kar, S. K., Sharma, N., Verma, S. K., \& Kaushal, V. (2020). Study of knowledge, attitude, anxiety \& perceived mental healthcare need in Indian population during COVID-19 pandemic. Asian journal of psychiatry, 51, 102083. doi: 10.1016/j.ajp.2020.102083

13.Rukmini, S. How covid-19 response disrupted health services in rural India. (2020, April 27th). Mint. Retrieved from https://www.livemint.com/news/india/how-covid-19-response-disruptedhealth-services-in-rural-india-11587713155817.html

14.Singh, P. (2020, May 3rd). Non-COVID-19 Patients Are Paying the Price of India's Efforts Against the Coronavirus. Science The Wire. Retrieved from https://science.thewire.in/health/healthcarenon-coronavirus-patients/

15.Wolf, M. S., Serper, M., Opsasnick, L., O'Conor, R. M., Curtis, L. M., Benavente, J. Y., ... \& Russell, A. (2020). Awareness, attitudes, and actions related to COVID-19 among adults with chronic conditions at the onset of the US outbreak: a cross-sectional survey. Annals of internal medicine. 173(2), 100-109. doi:10.7326/M20-1239

16.Yassa, M., Birol, P., Yirmibes, C., Usta, C., Haydar, A., Yassa, A., ... \& Tug, N. (2020). Near-term pregnant women's attitude toward, concern about and knowledge of the COVID-19 pandemic. The Journal of Maternal-Fetal \& Neonatal Medicine, 1-8. doi: 10.1080/14767058.2020.1763947

17. Zhou, J., Liu, L., Xue, P., Yang, X., \& Tang, X. (2020). Mental health response to the COVID-19 outbreak in China. American Journal of Psychiatry, 177(7), 574-575.

https://doi.org/10.1176/appi.ajp.2020.20030304

\section{Reviewer:}

\section{Review Comments}

By: Dr. Balaji Jayakrishnan, Associatee Professor, Business School, Vellore Institute of Technology Chennai

A significant research work carried by the authors. The research paper clearly highlights the transformed behaviour of patients adopting to try online or tele-medical consultation. The research is well structured. The paper is suitable for publication. 